\title{
Stability Parameters and AMMI Analysis of Quinoa (Chenopodium quinoa Willd.)
}

\author{
Mohamed Ali", Ashraf Elsadek* and Emad Mohamed Salem* \\ Agronomy Department, Faculty of Agriculture, Assiut University, Assiut 71526 and \\ "Ecology and Dry Land Agriculture Division, Desert Research Center, El-Matarya, \\ Cairo 11753, Egypt.
}

\begin{abstract}
CCREENING for stable genotype entails estimating the genotype $(\mathrm{G}) \times$ environment $(\mathrm{E})$ interaction (GEI) in multi-environmental trials (MET). Quinoa is a nutritionally rich crop as a source of vitamins, minerals and essential amino acids. It has been introduced to many countries in diverse regions worldwide. We evaluated five genotypes of quinoa under ten environments including irrigated and rain-fed conditions across Egypt. We used several stability parameters as well as additive main effects and multiplicative interaction (AMMI) analysis to determine the best genotype for each environment/location across Egypt. Based on AMMI analysis of variance, the sum of squares (SS) of E, G, and GEI explained $\approx 78 \%, 14 \%$, $8 \%$, respectively, of the treatment sum of squares. The SS of interaction principal components analysis axis1 (IPCA1) and IPCA2 explained 75 and 18\%, respectively. KVL-SRA3 was the most stable genotype according to ecovalence value $\left(\mathrm{W}_{\mathrm{i}}\right)$, to deviation from regression coefficient value $\left(\mathrm{S}^{2} \mathrm{~d}_{\mathrm{i}}\right)$ of Eberhart and Russell and to IPCA1, IPCA2 and AMMI stability value (ASV). Regalona was the most unstable genotype based on the same parameters. These results were visualized using AMMI biplot analysis, which revealed that KVL-SRA3 was widely adapted to all environments unlike Regalona that was poorly adapted to most environments. The Spearman's rank correlation among different stability parameters was significantly variable for both the five-quinoa genotypes and the ten investigated environments. Our results indicated that most stability parameters were consistent with AMMI parameters in identifying stable genotypes with some exceptions according to the concept of each of stability parameter (agronomic or biological). This study is an important step to open doors for the adoption of an extraordinary nutritional crop in Egypt.
\end{abstract}

Keywords : Genotypexenvironment interaction, Additive main effects and multiplicative interaction, Adaptability, Seed yield, Rank correlation, Interaction principal components analysis axis.

\section{Introduction}

Quinoa (Chenopodium quinoa Willd.) originated in the Andes region and is considered an important crop in some parts of Latin America including Peru, Chile, Bolivia and Colombia due to its nutritional features (Bhargava et al., 2006). It is also known as pseudocereal (Koziol, 1993). The nutritional value of Quinoa seeds is superbly high and exceeds other cereal crops in proteins, essential amino acids, vitamins and minerals (Repo-Carrasco et al., 2003). For example, it contains high levels of lysine and methionine (Prakash \& Pal, 1998 and Bhargava et al., 2003). In addition to the high nutritional values of the seeds of quinoa, the leaves are rich in high quality proteins (albumins \& globulins, prolamins, and Glutelins \& insoluble-proteins), vitamins as well as minerals (Ca, P and Fe) (Repo-Carrasco et al., 2003). Because of its remarkably high nutritional value, quinoa was expanded worldwide (Comai et al., 2007). Furthermore, it is tolerant to a diverse range of abiotic stresses (Rao \& Shahid, 2012) such as drought, hear stress, frost and salinity (Fuentes \& Bhargava, 2011 and Ruiz et al., 2014, 2016). This high resistance to the abiotic stresses is resulting from a vast genetic diversity and unfavorable environmental conditions prevailing in the origin of the crop (Sanchez et al., 2003).

Quinoa has been introduced to several countries worldwide and shown high degree of adaptability

\#Corresponding author email: mali@aun.edu.eg

DOI:10.21608/agro.2018.2916.1094

C2018 National Information and Documentation Centre (NIDOC) 
in U.S.A, India, African countries and European countries (Jacobsen, 2003). It is a very promising crop under high salinity and drought conditions in Dubai, UAE and similar climatic regions in adjacent desert countries, e.g., Sinai Peninsula, Egypt (Shams, 2011 and Rao \& Shahid, 2012). The General Assembly of the United Nations announced 2013 as an international year of quinoa. Since then quinoa has spread worldwide, for example, in 2015, the cultivated area of quinoa has been dramatically changed from 0 in 2008 to 5000 ha in European countries including France, Spain and United Kingdom (Bazile et al., 2016). Globally, the number of countries cultivating quinoa has dramatically increased from 8 at the beginning of the eighties of the last century to 75 during the current decade (Bazile \& Baudron, 2015).

The main objectives of the Quinoa breeding program are seed yield and quality (Bertero et al., 2004). These breeding programs are essentially based on adaptability and targeted to specific environments (Aguilar \& Jacobsen, 2003). Quinoa cultivars show high genotype $\times$ environment interaction (GEI) under multi-environments trials (MET) (Bertero et al., 2004). The GEI negatively affects the response to selection in breeding programs. The high amount of phenotypic diversity in quinoa is mainly due to its high GEI (Ceccarelli, 1996); however, this high magnitude of GEI restrains the identification of genetically outstanding genotypes. Understanding and quantification of the effect of both G and GEI are essential to improve the selection in breeding programs (Curti et al., 2014). The MET might accomplish the same goal; in addition, it will help in identifying genotypes adapted either to specific environments or to a wider range of environments (van Eeuwijk et al., 2005).

The performance of a genotype across environments can be evaluated via several univariate stability parameters. For example, GEI effects for each genotype can be squared and summed over all environments as ecovalence $\left(\mathrm{W}_{\mathrm{i}}\right)$ (Wricke, 1962). In addition, coefficient of regression $\left(b_{i}\right)$ of GEI effects on the environmental effects, deviation mean squares $\left(\mathrm{S}^{2} \mathrm{~d}_{\mathrm{i}}\right)$ and coefficient of determination (Eberhart \& Russell, 1966), regression coefficient of the GEI effects on the environmental effects (Perkins \& Jinks, 1968), coefficient of variation (CV) (Francis \& Kannenberg, 1978), superiority measure
$\left(\mathrm{P}_{\mathrm{i}}\right)$ (Lin \& Binns, 1988), and nonparametric stability statistics (Nassar \& Hühn, 1987) can be used to evaluate the stability of genotypes. The abovementioned stability parameters were critizised to not give enough information about the response pattern over wide range of environments (Lin et al., 1986). Utilizing multivariate statistics, e.g., additive main effects and multiplicative interaction (AMMI) model, which delivers a multivariate analytical parameter for inferring GEI (Crossa et al., 1991), enables extrapolation to a much wider environments than those tested, by characterizing the response patterns of genotypes to environmental change.

The magnitude of GEI in the MET detected via statistical analyses can be utilized to measure the stability of genotypes (Campbell \& Jones, 2005). Several statistical approaches were employed to detect both GEI and stable genotypes. The additive main effects and multiplicative interaction (AMMI) model is one of these various statistical approaches, which uses both the combined analysis of variance (ANOVA) and principal component analysis (PCA) (Gauch \& Zobel, 1997).

In the AMMI model, the total variance of the ANOVA is divided into three constituents including genotype $(\mathrm{G})$, environment $(\mathrm{E})$, genotype $\times \mathrm{E}$ interaction (GEI); consequently, the PCA is utilized to decompose the GEI into various interaction principal components analysis axes (IPCA). Statistically, the IPCA can be tested for significance via ANOVA. Finally, the AMMI model can be fully elucidated by visualization of the IPCA using biplots. The AMMI model was fully explained by Gauch \& Zobel (1996) and Annicchiarico (1997). Two methods of biplot analysis can be used to visualize GEI. Firstly, the AMMI biplot analysis (Gauch, 1988 and Zobel et al., 1988). Secondly, the genotype main effect + GEI (GGE) biplot analysis (Yan et al., 2000). The AMMI model biplot analysis can be used with either one PC (AMMI) or two PCs (AMMI2) (Yang et al., 2009). Both AMMI1 and AMMI2 can be utilized to visualize the mean performance and stability of genotypes (Gauch \& Zobel, 1997; Yan et al., 2007 and Gauch et al., 2008). The AMMI2 biplot analysis was fully described by Yang et al. (2009).

The AMMI analysis has advantages compared with genotype main effect and GEI 
(GGE) because the AMMI biplot graph catches exceedingly GEI rather than GGE graph and thus shows more accurate "which-won-where" model (Gauch, 2008). The AMMI biplot analysis is very convenient to elucidate the GEI and is consistent with the classical approach of Eberhart and Russell (Miranda et al., 2009).

Genotypes, which possess low IPCA1 and IPCA2 values are more stable over all environments. However, IPCA1 and IPCA2 may rank genotypes in diverse order in terms of stability; therefore, ASV might be a better alternative to identify stable genotypes than using both IPCA1 and IPCA2 (Caliskan et al., 2007). The rank of genotypes in terms of their stability can be developed utilizing AMMI stability value (ASV), which uses IPCA1 and IPCA2 as per Purchase (1997).

The key challenges for cultivation of quinoa in Egypt are the limited availability of genetic material, lack of knowledge about adaptability and stability of genetic material in different environments, poor knowledge of agronomical practices, lack of knowledge about the nutritional benefits of quinoa, and shortage of marketing outlets. We decided to focus on the genotype $\times$ environment interaction (GEI) to investigate adaptability and stability of genetic materials across Egypt. Therefore, the main objective of the current study was to use stability parameters and AMMI analysis and its parameters to identify the most stable genotypes of quinoa in different environments across Egypt.

\section{Materials and Methods}

Plant material and growth condition

A set of five genotypes of quinoa (Chenopodium quinoa Willd.) (KVL-SRA2, KVL-SRA3, Regalona, Q-37 and Q-52) were grown under irrigated and rainfed conditions across Egypt. The seeds of these genotypes were obtained from plant breeding unit, Plant Genetic Resources Department, Desert Research Center, Ministry of Agriculture, Egypt. We carried out the current experiment using a very limited number of quinoa genotypes because these were the only available genotypes provided by the Ministry of Agriculture in Egypt as this crop is currently new in Egypt with very limited genotypic resources.

These five genotypes were grown at four location across Egypt (Assiut, EL-Kharga, Matrouh and Ras Sudr) during 2015/2016 and 2016/2017 seasons. All these locations were irrigated except Matrouh location that included two conditions; irrigated (I) and rainfed (R). These locations displayed diversified environments in Egypt (Table $1)$. Each genotype was sown in three replications in $3.5 \times 4 \mathrm{~m}^{2}$ plots. Each plot consisted of six rows each $4 \mathrm{~m}$ long with $35 \mathrm{~cm}$ between rows and $25 \mathrm{~cm}$ inter-plant spacing. For the two growing seasons, no fertilizers were applied.

TABLE 1. Description of experimental locations.

\begin{tabular}{|c|c|c|c|c|}
\hline \multirow[t]{2}{*}{ Agro-ecological character } & \multicolumn{4}{|c|}{ Locations } \\
\hline & Assiut & El-Kharga & Matrouh & Ras Sudr \\
\hline Latitude & $27.18^{\circ} \mathrm{N}$ & $25.45^{\circ} \mathrm{N}$ & $31.35^{\circ} \mathrm{N}$ & $29.54^{\circ} \mathrm{N}$ \\
\hline Longitude & $31.16^{\circ} \mathrm{E}$ & $30.53^{\circ} \mathrm{E}$ & $27.18^{\circ} \mathrm{E}$ & $32.73^{\circ} \mathrm{E}$ \\
\hline Altitude (masl) & $53.00 \mathrm{~m}$ & $78.8 \mathrm{~m}$ & $9.00 \mathrm{~m}$ & $16.00 \mathrm{~m}$ \\
\hline $\begin{array}{l}\text { Annual rainfall }{ }^{\dagger}(\mathrm{mm}) \\
(2015 / 2016)\end{array}$ & $1.00 \mathrm{~mm}$ & $0.00 \mathrm{~mm}$ & $230.00 \mathrm{~mm}$ & $8.50 \mathrm{~mm}$ \\
\hline $\begin{array}{l}\text { Annual rainfall }(\mathrm{mm}) \\
(2016 / 2017)\end{array}$ & $1.00 \mathrm{~mm}$ & $0.00 \mathrm{~mm}$ & $105.50 \mathrm{~mm}$ & $9.25 \mathrm{~mm}$ \\
\hline $\begin{array}{l}\left.\text { Maximum temperature }{ }^{\ddagger}{ }^{\circ} \mathrm{C}\right) \\
(2015 / 2016)\end{array}$ & 25.84 & 28.10 & 22.11 & 24.82 \\
\hline $\begin{array}{l}\text { Maximum temperature }\left({ }^{\circ} \mathrm{C}\right) \\
(2016 / 2017)\end{array}$ & 25.07 & 27.57 & 21.25 & 24.19 \\
\hline $\begin{array}{l}\text { Minimum temperature }\left({ }^{\circ} \mathrm{C}\right) \\
(2015 / 2016)\end{array}$ & 11.00 & 12.94 & 12.71 & 14.26 \\
\hline $\begin{array}{l}\text { Minimum temperature }{ }^{\ddagger}\left({ }^{\circ} \mathrm{C}\right) \\
(2016 / 2017)\end{array}$ & 10.81 & 12.60 & 12.44 & 13.85 \\
\hline Soil type & Clay & Sandy clay loam & Sandy clay loam & Loamy Sand \\
\hline
\end{tabular}

${ }^{\dagger}$ Rainfall data were obtained from the Global Summary of the Day (GSOD) dataset of the National Climatic Data Center NNDC (ftp:// ftp.ncdc.noaa.gov/pub/data/gsod/) for the two growing seasons (2015/2016 and 2016/2017).

* Average temperature was calculated from the daily temperature data over the two growing seasons. Data were downloaded for the period from the first of October to the end of April (the growing season of the winter crops). 


\section{Trait studied}

At harvest, seed yield (SY; ton/ha) were measured for each plot in all experiments.

\section{Statistical analysis}

Univariate and nonparametric stability parameters (Wricke, 1962; Eberhart \& Russell 1966; Perkins \& Jinks, 1968; Francis \& Kannenberg, 1978; Lin \& Binns, 1988 and Nassar \& Hühn, 1987) were calculated for SY (ton/ha) using Genotype $\times$ Environment Analysis with $\mathrm{R}$ for Windows, Version 4.0 (GEA-R) (Pacheco et al., 2016). Wricke (1962) used GEI effects for each genotype, squared and summed over all environments was considered as a stability measure [ecovalence $\left(\mathrm{W}_{\mathrm{i}}\right)$ ]. The term ecovalence measures the contribution of a genotype to the GEI. Thus, a stable genotype possesses $\mathrm{W}_{\mathrm{i}}$ value near to zero. Consequently, based on the interpretation of the term ecovalence, stable genotype possesses a high ecovalence (low $\mathrm{W}_{\mathrm{i}}$ $=$ high ecovalence). Eberhart \& Russell (1966), on the contrary, defined a genotype with $b_{i}=1$ to be stable; this definition is in accordance with the dynamic concept. Coefficient of regression $\left(b_{i}\right)$ and deviation mean square $\left(\mathrm{S}_{\mathrm{di}}{ }^{2}\right)$ describe the contribution of genotype $i$ to GEI. Nassar \& Hühn (1987) used two parameters including mean rank difference $\left(\mathrm{S}_{\mathrm{i}}^{(1)}\right)$ and variance rank difference $\left(\mathrm{S}_{i}^{(2)}\right)$. For a genotype with maximum stability, $\mathrm{S}_{i}^{(1)}=0 . \mathrm{S}_{i}^{(2)}$ gives the variance among the ranks over the $\mathrm{N}$ environments and is also of general interest in other applications. Zero variance is indicative of maximum stability. Superiority measure $\left(\mathrm{P}_{\mathrm{i}}\right)$ was calculated as per Lin \& Binns (1988). The smaller the $\mathrm{P}_{\mathrm{i}}$ value the better judged are the genotype. The genotypes with the AMMI stability value (ASV) close to zero are the most stable ones (Purchase, 1997). Furthermore, he AMMI analysis was performed using AMMISOFT Version 1.0 (Gauch, 2013) for the same trait.

The AMMI model combines both ANOVA and PCA. In the ANOVA, the total variation is portioned into three constituents $(\mathrm{G}, \mathrm{E}$ and GEI); moreover, PCA is performed to divide the GEI into interaction principal component axes (IPCA). The significance test of the IPCA can be carried out using ANOVA. Furthermore, Gauch (1992) developed the following calculations to preclude false interpretation of the GEI results. They eliminated the uncontrolled variation (noise) from sum of squares of GEI (GEI SS) because most of the noise can be found in the GEI, which is attributed to its high degrees of freedom (df). Gauch (1992) described his approaches to calculate noise SS, real structure SS, and target relevant variation. Briefly, noise $\mathrm{SS}=\mathrm{MS}$ error $\times$ df (GEI), real structure SS $=$ GEI SS - noise SS, total relevant variation within the total treatment $\mathrm{SS}=$ Genotype SS + real structure SS. Therefore, the target relevant variation attributed to IPCA in the AMMI analysis = relevant variation $\mathrm{SS} /$ treatment SS.

The AMMI stability value (ASV) was performed as a specific stability parameter with a view to rank genotypes (Purchase, 1997).

Genotypes with lower values of IPCA1, IPCA2 and ASV are considered more stable across environments.

The Spearman's coefficient of rank correlation (Spearman 1904, Steel et al., 1980) was performed to compare the aforementioned univariate and nonparametric stability parameters as well as ASV using CORR procedure in SAS v9.0 (The SAS Institute Inc., Cary, NC, USA).

\section{$\underline{\text { Results }}$}

Separate and combined analyses of variance

Based on the separate and the combined analyses of variance of the current study (Table 2 ), the genotypes followed almost similar pattern in the two years for showing significant differences for seed yield (ton/ha) except in ElKharga location for the two years and in Assiut location for 2015/2016. Furthermore, genotypes showed significant differences for seed yield (ton/ha) based on the combined analysis of variance overall years and locations. In addition, all sources of variation in the combined analysis showed significant differences except Years $\times$ Loc $\times$ Gen.

The significant differences of the interactions between locations and genotypes on one hand and locations and years, on the other hand, implies the high effects of the location in the genotypeby-environment interaction. This indicates the importance of applying both stability parameters and AMMI analysis.

\section{Genotypic stability analyses}

Based on ecovalence $\left(\mathrm{W}_{\mathrm{i}}\right)$ stability coefficient, KVL-SRA3, Q-37 and Q-52 were considered as 
most stable (Table 3). Whereas, Regalona and KVL-SRA2 were rather unstable. For the stability parameters of Eberhart \& Russell (1966), KVLSRA2, Regalona and KVL-SRA3 were the most stable genotypes with the closest $b_{i}$ values to 1.0; on the other hand, Q-37 and Q-52 were the least stable genotypes. Genotypes KVL-SRA3, Q-37 and Q-52 were the most stable genotypes as they showed the smallest deviation from the regression values $\left(S^{2} d_{i}\right)$ unlike Regalona, which possessed the highest value of $S^{2} d_{i}$. Based on $R^{2}$, the predictabilities percentage of genotypes were relatively high for all genotypes for SY. These values extended from $86.17 \%$ for Regalona to $97.96 \%$ for Q-37. According to coefficient of variability (CV \%), Q-37 showed the lowest value $(\mathrm{CV} \approx 15.0 \%)$ with an average yield above the grand mean, unlike KVL-SRA2 which had the highest value $(\mathrm{CV} \approx 24.0 \%)$ with an average yield below the grand mean. Regalona and Q-37 were the most stable genotypes based on the superiority value $\left(\mathrm{P}_{\mathrm{i}}\right)$ of Lin \& Binns (1988), on the other hand, KVL-SRA2 $\left(\mathrm{P}_{\mathrm{i}}=0.1975\right)$ was less adapted in the investigated environments. For the nonparametric stability parameters of Nassar \& Hühn (1987), KVL-SRA2 showed the lowest stability based on the mean of absolute rank differences among all genotypes over all tested environments. However, the same genotype was the most stable genotype according to variance among the ranks over all the investigated environments. The order of genotypes based on their lowest score of IPCA1 was KVL-SRA3, Q-37, Q-52, KVL-SRA2, and Regalona. On the other hand, the order of these genotypes according to IPCA2 was slightly different from IPCA1 (KVL-SRA3, Q-37, Q-52, Regalona, and KVL-SRA2). Whereas, the order of genotypes according to ASV was the same as per IPCA1. Based on the IPCA1, IPCA2 and ASV, KVLSRA3 was the most stable genotype with mean SY of 2.3620 ton/ha, which was higher than the grand mean (2.35831 ton/ha). Regalona (2.6016 ton/ha), KVL-SRA2 (2.0817 ton/ha) and Q-52 (2.3493 ton/ha) scored the highest values for IPCA1. The highest IPCA2 scores were recorded by KVL-SRA2 (2.0817 ton/ha), Q-52 (2.3493 ton/ha) and Regalona (2.6016 ton/ha). However, the highest ASV scores were found in Regalona (2.6016 ton/ha), KVL-SRA2 (2.0817 ton/ha) and Q-52 (2.3493 ton/ha). Therefore, the foremost unstable genotype based on both IPCA1 and ASV was Regalona. On the other hand, KVLSRA2 was the most unstable genotype according to IPCA2. The most unstable genotype was KVL-SRA2 with an average yield of 2.0817 ton/ ha less than the grand mean, i.e., 2.35831 ton/ ha, which was poor adapted to the environments under investigation.

\section{Environmental stability analyses}

Using ecovalence value $\left(\mathrm{W}_{\mathrm{i}}\right), \mathrm{MR} 16, \mathrm{AI} 17$, MR17 and KI17 possessed the highest values with the highest contribution to GEI; however, RI17, RI16, AI16 and MI17 showed minimum contribution to GEI as they had the lowest $\mathrm{W}_{\mathrm{i}}$ values (Table 4). Investigating environments according to coefficient of variability (CV \%) (Francis \& Kannenberg, 1978) showed that KI17, AI17, RI16 and RI17 had the lowest CV $\%$ because they had the smallest response for genotypes variability. Whereas, the genotypes responses showed the maximum variability and highest values of CV \% in MR16, MR17, MI16 and MI17. Environments KI16, RI16 and MR17 had the lowest regression coefficients unlike the rest of environments that had regression coefficients either slightly less than 1.0 or higher. Based on environmental variance $\left(\mathrm{S}^{2} \mathrm{~d}_{\mathrm{i}}\right)$, the most stable environments were RI16, MR16, RI17 and AI16, which had the minimum deviation from the mean unlike MI16, KI16, AI17 and MI17. According to environmental superiority, MI16, KI16, MR17 and RI16 were the most stable environments unlike AI16, MI17, AI17 and RI17. RI16, KI17 and MR17 had the lowest $\mathrm{R}^{2}$-values of $\approx 15 \%, 26 \%$ and $38 \%$, respectively; whereas, the remaining environments showed the highest values ranged from $\approx 83 \%$ to $99 \%$. Based on nonparametric stability parameters, MRI16 and AI16 showed the lowest values among all environments for mean of absolute rank differences indicating that these two environments were less stable. On the other hand, the same environments were the most stable environments according to the variance among the ranks over tested environments. Based on IPCA1 scores for environments, the most stable environments were RI17, MI17, RI16 and AI16 unlike MR16, AI17, KI17 and MR17. On the other hand, environments AI16, AI17, KI17 and RI17 were the most stable environments with the lowest IPCA2; whereas, MI16, KI16, MR17 and MR16 were not well adapted under the investigated environments. According to ASV values, RI17, MI17, RI16 and AI16 were the most stable environments unlike MR16, AI17, KI17 and MR17. 
TABLE 2. Mean squares for seed yield (SeedY; ton/ha).

\begin{tabular}{|c|c|c|c|c|c|c|c|}
\hline \multicolumn{5}{|c|}{ Separate analysis } & \multicolumn{3}{|c|}{ Combined analysis } \\
\hline \multirow[b]{2}{*}{ Loc } & \multirow[b]{2}{*}{ Source } & \multirow[b]{2}{*}{ DF } & \multicolumn{2}{|c|}{ MS } & \multirow[b]{2}{*}{ Source } & \multirow[b]{2}{*}{ DF } & \multirow[b]{2}{*}{ MS } \\
\hline & & & $2015 / 2016$ & $2016 / 2017$ & & & \\
\hline \multirow{3}{*}{ Assiut } & Rep & 2 & 0.1230 & 0.1606 & Year & 1 & $0.3735^{* *}$ \\
\hline & Gen & 4 & 0.0878 & $1.35346^{* *}$ & Loc & 4 & $5.4595^{* * *}$ \\
\hline & Error & 8 & 0.0418 & 0.0818 & Year $\times$ Loc & 4 & $0.3792^{* * *}$ \\
\hline \multirow{3}{*}{ EL-Kharga } & Rep & 2 & 0.0104 & 1.0805 & Year×Loc (Rep) & 20 & $0.0259^{*}$ \\
\hline & Gen & 4 & 0.0499 & 1.1684 & Gen & 4 & $1.0295^{* * *}$ \\
\hline & Error & 8 & 0.0240 & 0.6042 & Year $\times$ Gen & 4 & $0.0490^{* *}$ \\
\hline \multirow{3}{*}{ Matrouh $(\mathrm{I})^{\dagger}$} & Rep & 2 & 0.0003 & 3.3591 & Loc $\times$ Gen & 16 & $0.1295^{* * *}$ \\
\hline & Gen & 4 & $0.2593^{* * *}$ & $7.6483^{* *}$ & Year $\times$ Loc $\times$ Gen & 16 & 0.0114 \\
\hline & Error & 8 & 0.0057 & 1.0184 & Error & 80 & 0.0124 \\
\hline \multirow{3}{*}{$\operatorname{Matrouh}(\mathrm{R})^{*}$} & Rep & 2 & 0.0006 & 0.0886 & & & \\
\hline & Gen & 4 & $0.5434^{* * *}$ & $1.14924^{* * *}$ & & & \\
\hline & Error & 8 & 0.0067 & 0.0349 & & & \\
\hline \multirow{3}{*}{ Ras Sudr } & Rep & 2 & 0.0002 & 0.0001 & & & \\
\hline & Gen & 4 & $0.0882^{* * *}$ & $0.0407^{* * *}$ & & & \\
\hline & Error & 8 & 0.0002 & 0.0003 & & & \\
\hline
\end{tabular}

$*, * * * * *$ Significant at the $0.05,0.01$ and 0.001 probability level, respectively. $\dagger$ Matrouh $(\mathrm{I})=$ Matrouh under irrigated condition; $\$$ Matrouh $(\mathrm{R})=$ Matrouh under rain-fed condition.

TABLE 3. Mean seed yield (SY; ton/ha) and genotypic stability parameters (ecovalence $\left(W_{i}\right) ; b_{i}=$ The coefficient of regression; $S^{2} d_{i}=$ Variance of deviation of regression; $R^{2}=$ Coefficient of determination; $C V \%=$ Coefficient of variation expressed as percentage; $P_{i}=$ Superiority measure; $S_{i}^{(1)}=$ Mean rank difference; $S_{i}^{(2)}=$ Variance rank difference; IPCA1 $=$ First interaction principal components analysis axis; IPCA2 $=$ Second interaction principal components analysis axis; $\mathrm{ASV}=\mathrm{AMMI}$ stability value) for five quinoa genotypes across 10 environments.

\begin{tabular}{|c|c|c|c|c|c|c|c|c|c|c|c|c|}
\hline \multirow{2}{*}{ Gen $^{\dagger}$} & \multirow{2}{*}{ Mean } & \multirow{2}{*}{$\begin{array}{c}\text { Wricke } \\
\text { (1962) } \\
W_{i}\end{array}$} & \multicolumn{3}{|c|}{$\begin{array}{c}\text { Eberhart \& Russell } \\
\text { (1966) }\end{array}$} & \multirow{2}{*}{$\begin{array}{c}\begin{array}{c}\text { Francis \& } \\
\text { Kannenberg } \\
\text { (1978) }\end{array} \\
\text { CV\% }\end{array}$} & \multirow{2}{*}{$\begin{array}{c}\text { Lin \& } \\
\text { Binns } \\
(\mathbf{1 9 8 8}) \\
\mathbf{P}_{\mathrm{i}}\end{array}$} & \multicolumn{2}{|c|}{$\begin{array}{c}\text { Nassar \& } \\
\text { Hühn (1987) }\end{array}$} & \multicolumn{3}{|c|}{ AMMI model } \\
\hline & & & $\mathbf{b}_{\mathrm{i}}$ & $\mathbf{S}^{2} \mathbf{d}_{\mathrm{i}}$ & $\begin{array}{l}\mathbf{R}^{2} \\
(\%)\end{array}$ & & & $\mathbf{S}_{\mathbf{i}}^{(\mathbf{1})}$ & $\mathbf{S}_{\mathbf{i}}^{(2)}$ & IPCA1 & IPCA2 & ASV \\
\hline KVL2 & 2.0817 & 0.3161 & 1.1099 & 0.0330 & 86.78 & 23.9962 & 0.1975 & 0.0000 & 0.0000 & -0.58583 & 0.3501 & 2.5102 \\
\hline KVL3 & 2.3620 & 0.0372 & 1.0214 & 0.0004 & 97.84 & 18.3291 & 0.0472 & 0.1800 & 0.7800 & 0.0521 & -0.0436 & 0.2252 \\
\hline REGL & 2.6016 & 0.3203 & 1.0968 & 0.0341 & 86.17 & 19.0407 & 0.0019 & 0.0900 & 1.1100 & 0.6075 & 0.2805 & 2.5928 \\
\hline Q-37 & 2.3971 & 0.0579 & 0.8534 & -0.0011 & 97.96 & 15.0806 & 0.0367 & 0.1800 & 0.8900 & 0.1408 & -0.2502 & 0.6478 \\
\hline Q-52 & 2.3493 & 0.0854 & 0.9184 & 0.0052 & 94.68 & 16.8441 & 0.0637 & 0.1300 & 1.8900 & -0.2146 & -0.3368 & 0.9707 \\
\hline
\end{tabular}

"KVL2=KVL-SRA2; KVL3=KVL-SRA3; REGL=Regalona; Q-37= Q-37 and Q-52=Q-52.

Egypt. J. Agron. 40, No. 1 (2018) 
TABLE 4. Mean seed yield (SY; ton/ha) and environmental stability parameters (ecovalence $\left(\mathrm{W}_{\mathrm{i}}\right) ; \mathbf{b}_{\mathrm{i}}=\mathrm{The}$ coefficient of regression; $S^{2} d_{i}=$ variance of deviation of regression; $R^{2}=$ Coefficient of determination; $C V \%=$ Coefficient of variation expressed as percentage; $P_{i}=$ Superiority measure; $S_{i}^{(1)}=$ Mean rank difference; $S_{i}^{(2)}=$ Variance rank difference; IPCA1 = First interaction principal components analysis axis; IPCA2 = Second interaction principal components analysis axis; ASV= AMMI stability value) for 10 environments.

\begin{tabular}{|c|c|c|c|c|c|c|c|c|c|c|c|c|}
\hline \multirow[t]{2}{*}{$\mathbf{E n v}^{\dagger}$} & \multirow[t]{2}{*}{ Mean } & \multirow{2}{*}{$\begin{array}{c}\text { Wricke } \\
(1962)\end{array}$} & \multicolumn{3}{|c|}{$\begin{array}{c}\text { Eberhart \& Russell } \\
\text { (1966) }\end{array}$} & \multirow{2}{*}{$\begin{array}{c}\text { Francis \& } \\
\text { Kannenberg } \\
(1978)\end{array}$} & \multirow{2}{*}{$\begin{array}{c}\text { Lin \& } \\
\text { Binns } \\
(1988)\end{array}$} & \multicolumn{2}{|c|}{$\begin{array}{c}\text { Nassar \& Hühn } \\
(1987)\end{array}$} & \multicolumn{3}{|c|}{ AMMI model } \\
\hline & & & $\mathbf{b}_{\mathrm{i}}$ & $S^{2} d_{i}$ & $\mathbf{R}^{2}$ & & & $\mathbf{S}_{\mathbf{i}}^{(\mathbf{1})}$ & $\mathbf{S}_{\mathrm{i}}^{(2)}$ & IPCA1 & IPCA2 & ASV \\
\hline AI16 & 2.3413 & 0.0205 & 0.8519 & 0.0014 & 0.8505 & 7.3085 & 0.2941 & 0.3000 & 0.5000 & -0.0656 & 0.0791 & 0.2894 \\
\hline AI17 & 2.3440 & 0.1189 & 0.2061 & 0.0063 & 0.1525 & 4.1708 & 0.3016 & 0.8000 & 3.7500 & -0.3612 & -0.0955 & 1.5357 \\
\hline KI16 & 2.0649 & 0.0863 & 0.428 & 0.0093 & 0.3782 & 6.2434 & 0.5539 & 0.8000 & 2.0000 & -0.2711 & -0.2512 & 1.1773 \\
\hline KI17 & 1.9522 & 0.1027 & 0.2198 & 0.0019 & 0.257 & 4.114 & 0.6771 & 0.8000 & 2.0000 & -0.3468 & -0.1203 & 1.4763 \\
\hline MI16 & 2.5890 & 0.0772 & 1.4782 & 0.0108 & 0.8675 & 11.356 & 0.1385 & 0.2000 & 0.2500 & 0.2373 & 0.2760 & 1.0438 \\
\hline MI17 & 2.1064 & 0.0254 & 0.8321 & 0.0027 & 0.8151 & 8.1051 & 0.4988 & 0.7000 & 3.5000 & -0.0292 & 0.2028 & 0.2376 \\
\hline MR16 & 2.0221 & 0.2353 & 2.2819 & -0.0012 & 0.9865 & 21.0475 & 0.6108 & 1.1000 & 4.5000 & 0.5290 & -0.2094 & 2.2544 \\
\hline MR17 & 2.0366 & 0.1141 & 1.8341 & 0.0017 & 0.9614 & 17.0148 & 0.5832 & 0.5000 & 1.5000 & 0.3366 & -0.2430 & 1.4486 \\
\hline RI16 & 3.0238 & 0.0191 & 0.8587 & 0.001 & 0.8612 & 5.6692 & 0.0035 & 0.0000 & 0.0000 & -0.0427 & 0.1965 & 0.2671 \\
\hline RI17 & 3.1028 & 0.0174 & 1.0092 & 0.0013 & 0.8894 & 6.389 & 0.0000 & 0.0000 & 0.0000 & 0.0137 & 0.1651 & 0.1751 \\
\hline
\end{tabular}

${ }^{\dagger}$ AI16 = Assiut irrigated 2016; AI17 = Assiut irrigated 2017; KI16 = El-Kharga irrigated 2016; KI17 = El-Kharga irrigated 2017; MI16= Matrouh irrigated 2016; MI17 = Matrouh irrigated 2017; MR16 = Matrouh rain-fed 2016; MR17 = Matrouh rain-fed 2017; RI16 = Ras Sudr irrigated 2016; RI17 = Ras Sudr irrigated 2017.

AMMI analysis of variance

We found that the G, E and GEI showed very highly significant differences for SY (ton/ha) based on the AMMI analysis of variance (Table 5). The percentage of SS among environments (E), genotypes (G) and GEI were $78.32 \%, 13.59 \%$ and $8.09 \%$ of the treatment SS, respectively. The pertinent part of the sum of squares due to treatment disregarding the environment constituent main effect, is (sum of squares due to genotypes + sum of squares due to GEI $=(4.12+2.45)=6.547$ or $21.68 \%$ of the sum of squares attributed to treatment. The GEI comprised $18.23 \%$ noise ([pure error mean squares $\times$ GEI degrees of freedom]/ GEI sum of squares]) and $81.77 \%$ real structure (GEI signal) ([sum of squares due to GEI - sum of squares due to noise]/sum of squares attributed to GEI). In addition, the sum of squares due to relevant variation $=[$ sum of squares due to genotypes + sum of squares due to real structure $]=[4.12+2.00=6.12]$. Therefore, the target variation percentage of the treatment SS ([relevant SS/treatment SS] $\times 100$ ) was $20.21 \%$. Furthermore, The GEI was divided into three interaction principal component axes (IPCA). The first two IPCAs were significant and explained 74.65 and $17.59 \%$ of the GEI SS, respectively, for SY (t/ha). Whereas, the third IPCA was not significant and accounted for only $5.94 \%$ of the GEI SS. The IPCA 1 constituent explained $19.63 \%$ of the treatment SS $((1.82917+4.11929) / 30.30096)$ which was almost the same as the target percentage sum of squares explained (20.21\%).

The GEI possessed 36 degrees of freedom, which represents the majority of degrees of freedom for treatment, and the noise presented a small portion of the sum of squares attributed to treatment; therefore, the GEI was noisier than SY over all replications. The sum of squares due to treatment was 30.30 with 49 degrees of freedom comprised $49 \times 0.01241=0.60809$ noise and 29.69287 real structure, therefore, the ratio of real structure to noise $(29.69287 / 0.60809)$ was 48.82973 . On the other hand, the same ratio in case of GEI (2.00357/ 0.44676 ) was 4.484667.

Incidentally, because the interaction has most of the treatment $\mathrm{df}$ and hence noise but has only a fraction of the treatment SS, interaction is much noisier than the data (yield averages across replications). The data of 3842.13 with $255 \mathrm{df}$ contain $255 \times 2.035=518.93$ noise and 3323.20 pattern, so its $\mathrm{S} / \mathrm{N}$ ratio is $3323.20 / 518.93=$ 6.40. However, the interaction $\mathrm{S} / \mathrm{N}$ ratio is only $280.15 / 457.88=0.61$, which is ten times smaller. The general lesson to be learned here is that the interaction is buried by noise more quickly than genotype and environment main effects. 
TABLE 5. Additive main effects and multiplicative interaction (AMMI) analysis of variance for seed yield (SY; ton/ ha) of five quinoa genotypes across 10 environments.

\begin{tabular}{lcccc}
\hline Source & df & SS & MS $^{\dagger}$ & Explained SS (\%) of Treatment SS \\
\hline Total & 149 & 31.81212 & 0.2135 & \\
TRT & 49 & 30.30096 & $0.61839^{* * *}$ & 13.59 \\
GEN (G) & 4 & 4.11929 & $1.02982^{* * *}$ & 78.32 \\
ENV (E) & 9 & 23.73135 & $2.63682^{* * *}$ & 8.09 \\
G×E & 36 & 2.45033 & $0.06806^{* * *}$ & 74.65 \\
IPC1 & 12 & 1.82917 & $0.15243^{* * *}$ & 17.59 \\
IPC2 & 10 & 0.43111 & $0.04311^{* * *}$ & 5.94 \\
IPC3 & 8 & 0.14557 & 0.0182 & \\
Residual & 6 & 0.04447 & 0.00741 & \\
Error & 100 & 1.51116 & 0.01511 & \\
Blocks/Env & 20 & 0.51797 & $0.0259^{*}$ & \\
Pure Error & 80 & 0.99318 & 0.01241 & \\
\hline
\end{tabular}

$*, * *, * * *$ Significant at $\mathrm{P}<0.05, \mathrm{P}<0.01$ and $\mathrm{P}<0.001$ probability level, respectively.

${ }^{\dagger}$ F-tests use Pure Error because Blocks/Env are significant at the 0.05 level.

Spearman's rank correlation amongst stability parameters

The relationships among stability parameters were assessed using Spearman's rank correlation (Table 6). The average SY for the ten environments was significantly negatively correlated with $\mathrm{W}_{i}, \mathrm{P}_{i}, \mathrm{~S}_{i}^{(1)}, \mathrm{S}_{i}^{(2)}$, IPCA2 and ASV. Ecovalence $\left(\mathrm{W}_{\mathrm{i}}\right)$ stability parameter showed significantly positively correlation with $\mathrm{P}_{i}, \mathrm{~S}_{\mathrm{i}}^{(1)}, \mathrm{S}_{\mathrm{i}}^{(2)}$ and ASV. Regression coefficient $\left(b_{\mathrm{i}}\right)$ were significantly positively correlated with $\mathrm{R}^{2}, \mathrm{CV} \%$ and IPCA1. The coefficient of determination $\left(\mathrm{R}^{2}\right)$ was highly significantly positively correlated with $\mathrm{CV} \%$ and IPCA 1. The coefficient of variation ( $\mathrm{CV} \%$ ) was highly significantly positively correlated with IPCA1. The superiority stability parameter $\left(\mathrm{P}_{\mathrm{i}}\right)$ was positively significantly correlated with $\mathrm{S}_{i}^{(1)}$, $\mathrm{S}_{i}^{(2)}$ and $\mathrm{ASV}$; in addition, it was negatively significantly correlated with IPCA2. $\mathrm{S}^{(1)}$ was positively significantly correlated with $\mathrm{S}_{\mathrm{i}}{ }^{(2)}$ and $\mathrm{ASV}$; furthermore, it was negatively significantly correlated with IPCA2. $\mathrm{S}_{i}^{(2)}$ was positively significantly correlated with ASV. The IPCA2 score was negatively significantly correlated with ASV. For SY (ton/ha) of the five tested genotypes, the average SY had perfect and significant correlation with $\mathrm{P}_{i}$ and IPCA1. The $\mathrm{W}_{i}$ was wither perfectly correlated with ASV or significantly strongly correlated with $S^{2} d_{i}$ and $R^{2}$. The regression coefficient $\left(b_{i}\right)$ was perfectly correlated with $\mathrm{CV} \%$ and strongly correlated with IPCA2. The deviation from the regression values $\left(S^{2} d_{i}\right)$ was perfectly correlated with $\mathrm{R}^{2}$ and strongly positively correlated with ASV. The coefficient of determination was significantly negatively correlated with ASV. The coefficient of variation was significantly correlated with IPCA2. The superiority stability parameter $\left(\mathrm{P}_{\mathrm{i}}\right)$ was perfectly correlated with IPCA1.

\section{AMMI1 biplot}

Based on the AMMI biplot analysis (Fig. 1), KVL-SRA3 was the most widely adapted genotype unlike Regalona, which was not stable across environments but specifically adapted to Matrouh (I) 2016 (MI6). In addition, QQ-37 was adapted to Matrouh (R) 2017 (MR7) and QQ_52 was adapted to El-Kharga 2017 (KI6). 
TABLE 6. Spearman's rank correlation among different stability parameters for five quinoa genotypes across 10 environments (above diagonal, environmental correlation coefficient; below diagonal, genotypic correlation coefficient).

\begin{tabular}{|c|c|c|c|c|c|c|c|c|c|c|c|c|}
\hline & Mean & $\mathbf{W}_{\mathrm{i}}$ & $\mathbf{b}_{\mathrm{i}}$ & $S^{2} d_{i}$ & $\mathbf{R}^{2}$ & CV\% & $\mathbf{P}_{\mathrm{i}}$ & $\mathbf{S}_{\mathrm{i}}^{(\mathbf{1})}$ & $\mathbf{S}_{\mathrm{i}}^{(2)}$ & IPCA1 & IPCA2 & ASV \\
\hline Mean & & $-0.71^{*}$ & 0.04 & -0.01 & 0.07 & -0.15 & $-0.99 * *$ & $-0.80 * *$ & $-0.68^{*}$ & -0.02 & $0.67 *$ & $-0.67 *$ \\
\hline $\mathrm{W}_{\mathrm{i}}$ & 0.10 & & 0.01 & 0.15 & -0.04 & 0.19 & $0.78 * *$ & $0.85^{* *}$ & $0.81 * *$ & 0.04 & -0.61 & $0.95 * *$ \\
\hline$b_{i}$ & -0.30 & 0.6 & & -0.48 & $0.99 * *$ & $0.84^{* *}$ & -0.09 & -0.27 & -0.25 & $0.96^{* *}$ & 0.05 & -0.04 \\
\hline $\mathrm{S}^{2} \mathrm{~d}_{\mathrm{i}}$ & 0.00 & $0.90^{*}$ & 0.80 & & -0.56 & -0.19 & 0.05 & 0.15 & 0.14 & -0.38 & 0.09 & 0.07 \\
\hline $\mathrm{R}^{2}$ & 0.00 & $-0.90^{*}$ & -0.80 & $-1.00 * *$ & & $0.81 * *$ & -0.12 & -0.29 & -0.27 & $0.95 * *$ & 0.02 & -0.09 \\
\hline CV\% & -0.30 & 0.60 & $1.00 * *$ & 0.80 & -0.80 & & 0.10 & 0.01 & 0.11 & $0.90 * *$ & 0.02 & 0.03 \\
\hline $\mathrm{P}_{\mathrm{i}}$ & $-1.00 * *$ & -0.10 & 0.30 & 0.00 & 0.00 & 0.30 & & $0.85^{* *}$ & $0.74 *$ & -0.02 & $-0.68 *$ & $0.73 *$ \\
\hline $\mathrm{S}_{\mathrm{i}}^{(1)}$ & 0.36 & -0.87 & -0.82 & -0.87 & 0.87 & -0.82 & -0.36 & & $0.94 * *$ & -0.19 & $-0.64 *$ & $0.81 * *$ \\
\hline $\mathrm{S}_{\mathrm{i}}^{(2)}$ & 0.40 & 0.20 & -0.50 & 0.10 & -0.10 & -0.50 & -0.40 & 0.15 & & -0.12 & -0.45 & $0.70 *$ \\
\hline IPCA1 & $1.00 * *$ & 0.10 & -0.30 & 0.00 & 0.00 & -0.30 & $-1.00 * *$ & 0.36 & 0.40 & & 0.10 & -0.08 \\
\hline IPCA2 & -0.10 & 0.50 & $0.90^{*}$ & 0.60 & -0.60 & $0.90^{*}$ & 0.10 & -0.67 & -0.70 & -0.10 & & $-0.64 *$ \\
\hline ASV & 0.10 & $1.00 * *$ & 0.60 & $0.90^{*}$ & $-0.90^{*}$ & 0.60 & -0.1 & -0.87 & 0.20 & 0.10 & 0.50 & \\
\hline
\end{tabular}

*** Significant at $\mathrm{p}<0.05, \mathrm{p}<0.01$ probability level, respectively.

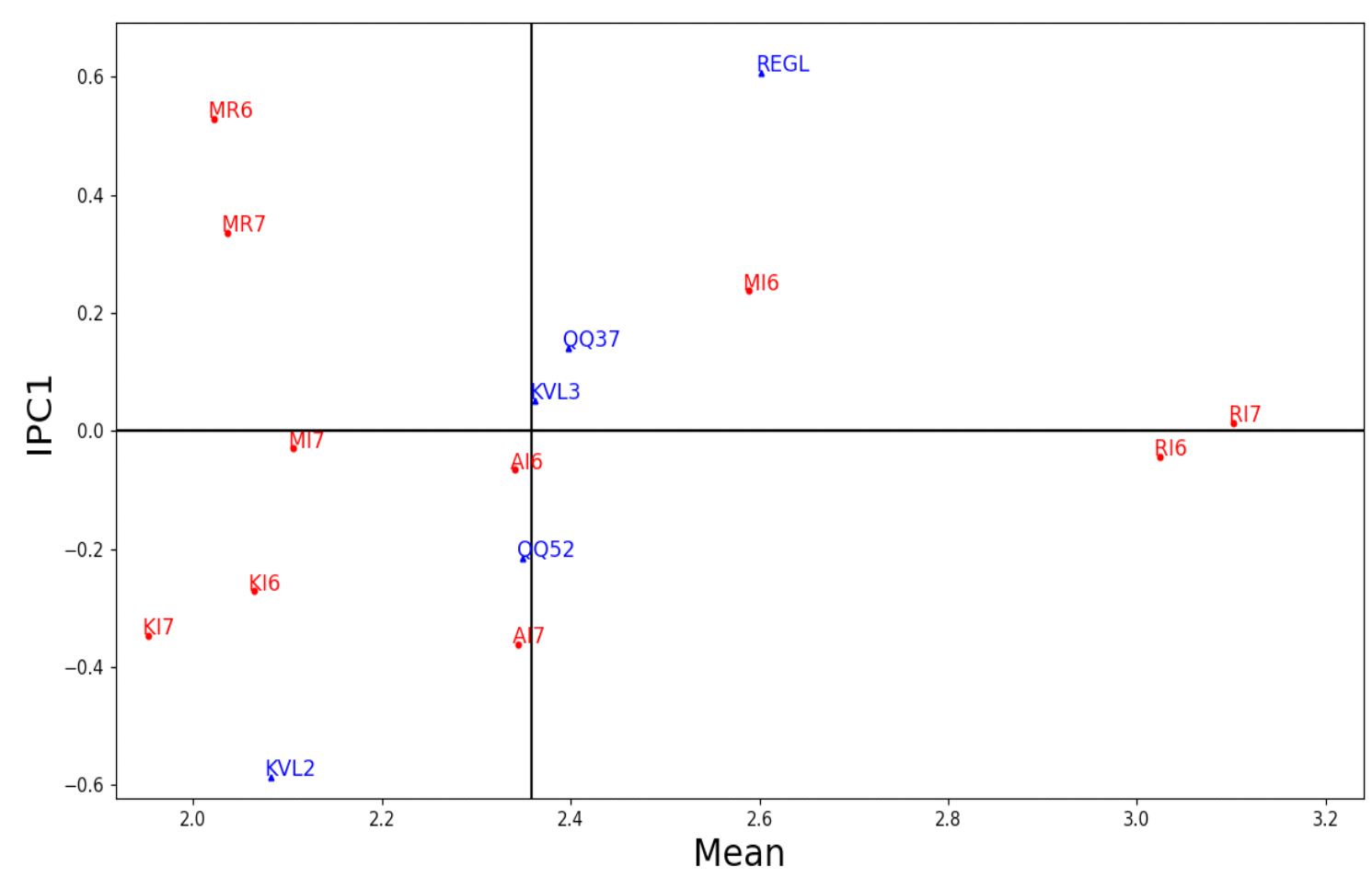

Fig. 1. AMMI biplot showing the mean seed yield (SY; ton/ha) and the first interaction principal component (IPC1) effects of both genotypes and environments on seed yield. The data represented the five quinoa genotypes (KVL2 = KVL-SRA2; KVL3 $=$ KVL-SRA3; REGL=Regalona; $Q Q 37=Q-37$ and QQ52= Q-52) and 10 environments $(\mathrm{AI} 6=$ Assiut irrigated 2016; $\mathrm{AI} 7$ $=$ Assiut irrigated 2017; KI6=EI-Kharga irrigated 2016; KI7 = El-Kharga irrigated 2017; MI6 = Matrouh irrigated 2016; MI7 = Matrouh irrigated 2017; MR6 = Matrouh rain-fed 2016; MR7 = Matrouh rain-fed 2017; RI6 = Ras Sudr irrigated 2016; RI7 = Ras Sudr irrigated 2017) for mean seed yield (SY; ton ha ${ }^{-1}$ ) using genotypic and environmental scores. 
Our study revealed that the AMMI1 biplot provided a model fit of $\approx 75 \%$. Different environments had different effects on the genotypes. Ras Sudr 2016 (RI6) and Ras Sudr 2017 (RI7) showed IPCA1 scores close to zero, with environmental mean being more than the grand mean. On the other hand, El-Kharga 2016 (KI6) and El-Kharga 2017 (KI7) had negative IPCA1 scores, with environmental mean less than the grand mean. Furthermore, Assiut 2016 and Assiut 2017 showed negative IPCA1 scores, with environmental means close to the grand mean, which revealed that these two environments had lower interaction effects than the rest of environments. In addition, Matrouh (R) 2016 and 2017 possessed high positive IPCA1 scores; with environmental means less than the grand mean; which indicated that these two environments had high interaction attributes.

\section{AMMI2 biplot}

The AMMI2 biplot depicted the relationship between IPCA1 and IPCA2 (Fig. 2); which can be exploited to elucidate the amount of interaction between genotypes and environments (Rashidi et al., 2013). The discriminative environments can be detected using the vector length in the AMMI biplot analysis (Li et al., 2003). Based on the comparisons among environments using the vector length, the best discriminative environments for quinoa genotypes were Matrouh (R) 2016 and 2017 as they have the longest vectors amongst all environments. Furthermore, other environments including Assiut (I) 2106 (AI6), Ras Sudr (I) 2016 (RI6) and 2017 (RI7), and Matrouh (I) 2017 (MI7) showed shorter vectors length, which indicated that they were not discriminative environments for the genotypes. Yan et al. (2000) indicated that the discriminative ability of environments for the genotypes under investigation could be determined via the vector length of the environments. Genotypes and environments; which located on the same side were positively interacted unlike those fallen on the different sides (Osiru et al., 2009). For example, we found acute angles between the vectors of environments Matrouh (R) 2016 (MR6) and Matrouh (R) 2017 (MR7). On the other, the angle between Matrouh (R) 2017 (MR7) and Matrouh (I) 2016 (MI6) were obtuse in opposite sides.

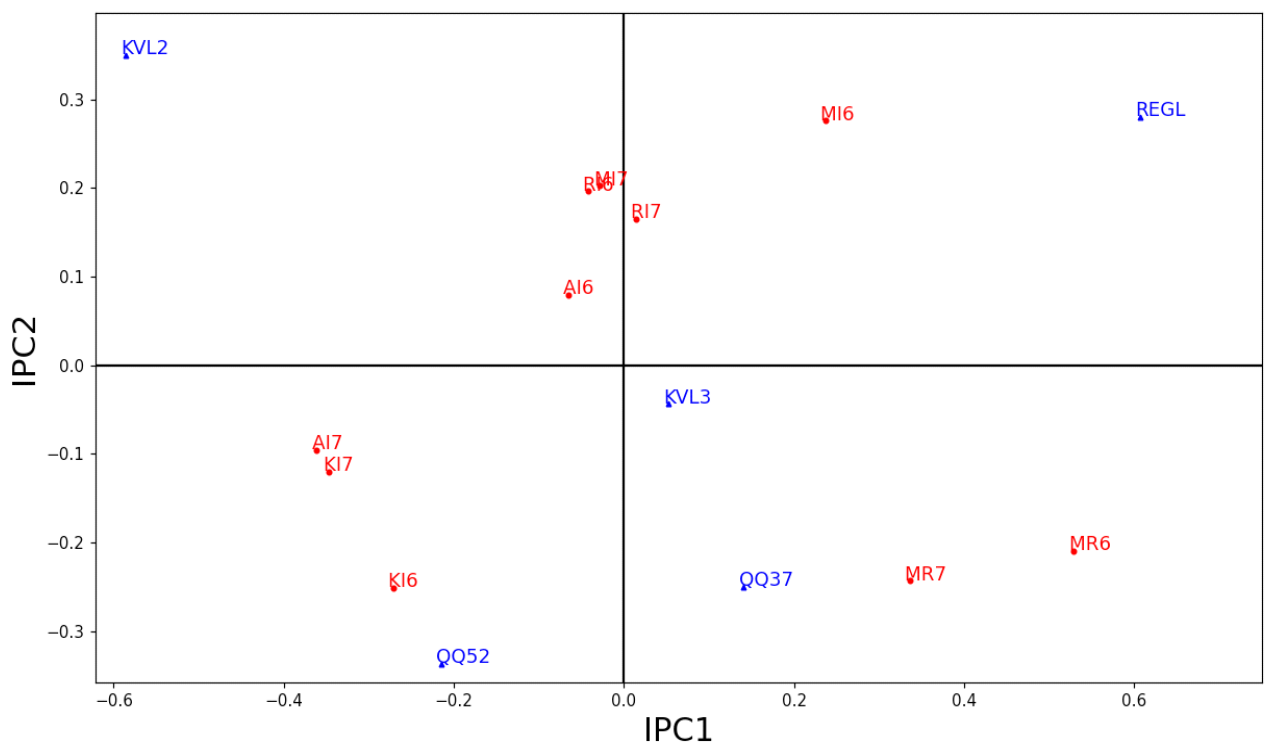

Fig. 2. Biplot of the second interaction principal component axis (IPCA2) against the first interaction principal component axis (IPCA1) scores for seed yield (SY; ton/ha) of five quinoa genotypes (KVL2 = KVL-SRA2; KVL3 = KVL-SRA3; REGL $=$ Regalona; QQ37 = Q-37 and QQ52 = Q-52) in 10 environments (AI6 = Assiut irrigated 2016; AI7 = Assiut irrigated 2017; KI6 = El-Kharga irrigated 2016; KI7 = El-Kharga irrigated 2017; MI6 = Matrouh irrigated 2016; MI7 = Matrouh irrigated 2017; MR6 = Matrouh rain-fed 2016; MR7 = Matrouh rain-fed 2017; RI6 = Ras Sudr irrigated 2016; RI7 = Ras Sudr irrigated 2017).

\section{Discussion}

The GEI vindicating that selection target environment/location is paramount for a successful breeding program (Atlin et al., 2001). Naturally, quinoa is very well adapted to low water requirements; therefore, it is intrinsically a drought tolerant crop (Zurita-Silva et al., 2014). 
In addition, it can grow under severe salinity, producing yield under high saline irrigation water similar to seawater (Adolf et al., 2012).

In a MET conducted in three continents to evaluate the degree and the nature of genotype (G) and genotype $\times$ environment $(\mathrm{G} \times \mathrm{E})$ effects, no single genotype performed well through all environments; therefore, the $\mathrm{G} \times \mathrm{E}$ constituent had the main effect on the performance of genotypes for seed and biological yields (Bertero et al., 2004).

Curti et al. (2014) fount that, in the combined analysis of variance of a MET through Argentina, the effects of both $\mathrm{G}$ and GEI were significant for all traits; moreover, the E effect was significant for SY. In the same study, they showed that the GEI effect explained higher amount of variation comparing to the $\mathrm{G}$ effect for SY; on the other hand, the $\mathrm{G}$ effect accounted for more variation than GEI effect for biomass yield and seed weight.

The PC1, PC2, PC3 explained 56.2\%, 23.3\%, $14 \%$ of the GEI, respectively (Curti et al., 2014). The SY can be significantly reduced in case of excessive irrigation (De Santis et al., 2016); this might be due to spread of diseases. We found that the SS for GEI-signal was 0.49 times that for GEN main effects. In addition, the GEI-noise was 0.11 times the GEN main effects. Discarding noise improves accuracy, increases repeatability, simplifies conclusions, and accelerates progress (Gauch, 2013).

The aim of a mega-environment (i.e. environments with the same cultivar as outstanding in a MET (Miranda et al., 2009) approach should not take in consideration the whole sum of squares attributed to treatment but disregarding the environment main effect; this pertinent ranged from 10 to $40 \%$ (Gauch \& Zobel, 1997). These results are consistent with our findings (21.68\%).

The ideal mega-environment analysis should focus on the target variation percentage of the treatment SS (Gauch \& Zobel, 1997), which is $20.21 \%$ in our study. Therefore, we should disregard the $79.79 \%$ attributed to environmental main effect along with noise effect. Consequently, catching $<20.21 \%$ underfits real and target forms in the data, and apprehending $>20.21 \%$ overfits noise and captures irrelevant structures in the data as indicated by Gauch \& Zobel (1997). Our results are in consistent with Gauch \& Zobel (1997) who stated that the percentage of target variation to detect mega-environment ranged from 10 to $40 \%$ of the treatment sum of squares.

Our calculations showed that the ration of real structure SS to noise SS based on GEI SS was 10 times less than the same ration based on treatment SS. These results were similar to those found by Gauch \& Zobel (1997). Accordingly, the GEI disappeared by noise more rapidly than genotypic and environmental main effects (Gauch \& Zobel, 1997)

The AMMI biplot analysis depicted the relationship between the IPCA1 scores and the mean yield of both genotypes and environments (Ali et al., 2015).Genotypes and environments that showed IPCA1 values near to zero were widely adapted; on the other hand, genotypes with high scores were more adapted to environments with IPCA1 scores of similar sign (Ebdon \& Gauch, 2002 and De Vita et al., 2010). Therefore, we considered KVL-SRA3 as widely adapted genotype whereas Regalona was specifically adapted to Matrouh (I) 2016. Most of the tested genotypes in the current study had IPCA1 scores far away from zero; which indicated that they were not stable across environments.

Vargas et al. (1999) summarized the use of angles between environments or genotypes to detect the relationship between environments or genotypes as the following: Acute angles between vectors of environments or genotypes referred to positive correlation, parallel vectors in the same directions showed a positive perfect correlation, obtuse angle revealed negative correlation, obtuse angle in opposite directions represented a negative perfect correlation, and perpendicular angle displayed no correlation. Therefore, the acute angle between Matrouh (R) 2016 and Matrouh (R) 2017 elucidated that these two environments were positively correlated and were related in their effects on genotypes response. On the other hand, the obtuse angle between Matrouh (R) 2017 and Matrouh (I) 2016 indicated that these two environments were negatively perfect correlated. This indicated that genotypes in these two environments responded inversely.

Some stability parameters showed that KVLSRA3 is the most stable genotype or one of the most stable genotypes across environments. 
However, other stability did not show the same result due to different concept of stability for different stability parameters. These concepts may be agronomic concept (i.e. a genotype with a yield that can be predicted based on the productivity of the environment, e.g. ecovalence, $\mathrm{W}_{\mathrm{i}}$ ) or biological concept (i.e. genotype with constant yield, e.g. regression measures) (Becker, 1981).

We investigated the relationship among the stability parameters using Spearman's rank correlation instead of Pearson's correlation, because the stability parameters cannot be considered as normally distributed (Becker, 1981). The correlation between $\mathrm{W}_{\mathrm{i}}$ and $\mathrm{S}^{2} \mathrm{~d}_{\mathrm{i}}$ was very strong $(r=0.90, p$-value $<0.05)$ for the five quinoa genotypes. This relationship was expected to be high because the $\mathrm{W}_{\mathrm{i}}$ value included two components; one of them is the $\mathrm{S}^{2} \mathrm{~d}_{\mathrm{i}}$ (Becker, 1981). However, this relationship was very weak and not significant for the five investigated genotypes; which might be due to the limited number of genotypes used in the current study.

The correlations between mean productivity and various stability parameters were significantly variable in case of genotypes and environments. These findings were consistent with Langer et al. (1979). For example, the mean productivity of the five quinoa genotypes showed negative and positive perfect correlation with $\mathrm{P}_{\mathrm{i}}$ and IPCA1, respectively. Furthermore, correlation between mean productivity of the ten environments and other stability parameters ranged from negative perfect correlation with $\mathrm{P}_{\mathrm{i}}$ to strong correlation with $\mathrm{W}_{\mathrm{i}}, \mathrm{S}_{\mathrm{i}}^{(1)}, \mathrm{S}_{\mathrm{i}}^{(2)}$, IPCA2 and ASV. Our results were consistent with Becker (1981) in terms of using different stability parameters may resulted in different ranking of genotypes which may alter the relationship among these parameters due to the different concepts of stability for each parameter. In addition, we did not detect any significant correlation between the regression coefficient $\left(b_{i}\right)$ value of Eberhart \& Russell and the superiority index $\left(\mathrm{P}_{\mathrm{i}}\right)$ of Lin \& Binn in contrary with the findings of Scapim et al. (2000). The nonparametric stability statistics $\mathrm{S}_{i}^{(1)}$ and $\mathrm{S}_{i}^{(2)}$ of Nassar \& Hühn (1987) were significantly strongly correlated with mean productivity of the ten environments and other stability parameters for genotypes including $\mathrm{W}, \mathrm{P}_{\mathrm{i}}$ and $\mathrm{ASV}$ in consistent with Scapim et al. (2000) who used corn genotypes. However, neither mean productivity of the five quinoa genotypes nor other stability parameters were significantly correlated with these nonparametric stability statistics.

\section{Conclusion}

Based on different stability parameters and AMMI biplot analysis, we found that KVL-SRA3 was widely adapted to diversified environments across Egypt unlike Regalona. Most stability parameters were consistent with AMMI parameters in detecting the stable and non-stable genotypes with some exceptions based on the concept of stability for each of the stability parameters in the current study. The correlation among various stability parameters of both the five quinoa genotypes and the ten environments were significantly variable.

Quinoa is considered as a good contributor for food security in the future; nevertheless, introducing quinoa to the Egyptian farmers and consumers is lagging behind. In Egypt, it may be grown in the marginal lands to avoid high competition with other important strategic crops, e.g. wheat. Quinoa is a good candidate, which might fill in the gap of the wheat production in Egypt. Subsequently, it is essential to develop new varieties adapted to the different regions in Egypt, especially, marginal lands and unfavorable sites. Due to its tolerance to diverse environments, quinoa may be grown in unfavorable environments.

This study is the first MET of quinoa in Egypt, which might help to adopt quinoa in Egypt as a new promising crop due to its extraordinary nutritional value. In addition, our study can help in identifying genotypes that are adapted to specific or wide range of environments. This might encourage other breeders to extensively evaluate more genotypes across Egypt and tackle adaptability and stability of quinoa.

Acknowledgements: The authors wish to thank Prof. Wolfgang Link, Georg-August-University, Goettingen, Germany, for his useful comments on this paper.

\section{References}

Adolf, V.I., Shabala, S., Andersen, M.N., Razzaghi, F. and Jacobsen, S.E. (2012) Varietal differences of quinoa's tolerance to saline conditions. Plant and Soil, 357, 117-129.

Aguilar, P.C. and Jacobsen, S.E. (2003) Cultivation of quinoa on the Peruvian Altiplano. Food Reviews International, 19, 31-41. 
Ali, M.B., El-Sadek, A.N., Sayed, M.A. and Hassaan, M.A. (2015) AMMI biplot analysis of genotypexenvironment interaction in wheat in Egypt. Egyptian Journal of Plant Breed. 19, 1889-1901.

Annicchiarico, P. (1997) Additive main effects and multiplicative interaction (AMMI) analysis of genotype-location interaction in variety trials repeated over years. Theoretical and Applied Genetics, 94, 1072-1077.

Atlin, G.N., Cooper, M. and Bjørnstad, Å. (2001) A comparison of formal and participatory breeding approaches using selection theory. Euphytica, 122, 463-475.

Bazile, D. and Baudron, F. (2015) The dynamics of the global expansion of quinoa growing in view of its high biodiversity. In: "State of the Art Report on Quinoa Around the World in 2013". D Bazile, H.D. Bertero, C. Nieto (Ed.), pp. 42-55. (FAO \& CIRAD Publishing: Rome)

Bazile, D., Jacobsen, S.E. and Verniau, A. (2016) The global expansion of quinoa: Trends and limits. Frontiers in Plant Science, 7, 6-22.

Becker, H.C. (1981) Correlations among some statistical measures of phenotypic stability. Euphytica, 30, $835-840$.

Bertero, H.D., De la Vega, A.J., Correa, G., Jacobsen, S.E. and Mujica, A. (2004) Genotype and genotype-by-environment interaction effects for grain yield and grain size of quinoa (Chenopodium quinoa Willd.) as revealed by pattern analysis of international multi-environment trials. Field Crops Research, 89, 299-318.

Bhargava, A., Shukla, S. and Ohri, D. (2003) Genetic variability and heritability of selected traits during different cuttings of vegetable Chenopodium. The Indian Journal of Genetics and Plant Breeding, 63, 359-360.

Bhargava, A., Shukla, S. and Ohri, D. (2006) Chenopodium quinoa - an Indian perspective. Industrial Crops and Products, 23, 73-87.

Caliskan, M.E., Erturk, E., Sogut, T., Boydak, E. and Arioglu, H. (2007) Genotypexenvironment interaction and stability analysis of sweetpotato (Ipomoea batatas) genotypes. New Zealand Journal of Crop and Horticultural Science, 35, 87-99.

Campbell, B.T., and Jones, M.A. (2005) Assessment of genotype $\times$ environment interactions for yield and fiber quality in cotton performance trials. Euphytica, 144, 69-78.

Ceccarelli, S. (1996) Positive interpretation of genotype by environment interactions in relation to sustainability and biodiversity. In: "Plant Adaptation and Crop Improvement". M Cooper, GL Hammer (Ed.), pp. 467-485. (CAB International/ ICRISAT \& IRRI Publishing: Wallingford, UK).

Comai, S., Bertazzo, A., Bailoni, L., Zancato, M., Costa, C.V. and Allegri, G. (2007) The content of proteic and nonproteic (free and protein-bound) tryptophan in quinoa and cereal flours. Food Chemistry, 100, 1350-1355.

Crossa, J., Fox, P.N., Pfeiffer, W.H., Rajaram, S. and Gauch, H.G. (1991) AMMI adjustment for statistical analysis of an international wheat yield trial. Theoretical and Applied Genetics, 81, 27-37.

Curti, R.N., de la Vega, A.J., Andrade, A.J., Bramardi, S.J. and Bertero, H.D. (2014) Multi-environmental evaluation for grain yield and its physiological determinants of quinoa genotypes across Northwest Argentina. Field Crops Research, 166, 46-57.

De Santis, G., D’Ambrosio, T., Rinaldi, M. and Rascio, A. (2016) Heritabilities of morphological and quality traits and interrelationships with yield in quinoa (Chenopodium quinoa Willd.) genotypes in the Mediterranean environment. Journal of Cereal Science, 70, 177-185.

De Vita, P., Mastrangelo,A.M., Matteu, L., Mazzucotelli, E., Virzi, N., Palumbo, M., Storto, M.L., Rizza, F. and Cattivelli, L. (2010) Genetic improvement effects on yield stability in durum wheat genotypes grown in Italy. Field Crops Research, 119, 68-77.

Ebdon, J.S. and Gauch, H.G. (2002) Additive main effect and multiplicative interaction analysis of national turfgrass performance trials. Crop Science, 42, 497-506.

Eberhart, S.T. and Russell, W.A. (1966) Stability parameters for comparing varieties. Crop Science 6, 36-40.

Francis, T.R. and Kannenberg,L.W.(1978)Yield stability studies in short-season maize. I. A descriptive method for grouping genotypes. Canadian Journal of Plant Science, 58, 1029-1034.

Fuentes, F. and Bhargava, A. (2011) Morphological analysis of quinoa germplasm grown under lowland desert conditions. Journal of Agronomy and Crop Science, 197, 124-134.

Gauch, H.G. (1988) Model selection and validation for yield trials with interaction. Biometrics, 44, 705-715. 
Gauch, H.G. (1992) "Statistical Analysis of Regional Yield Trials: AMMI Analysis of Factorial Designs". (Elsevier Science Publishing: Amsterdam, the Netherlands).

Gauch, H.G. (2013) A simple protocol for AMMI analysis of yield trials. Crop Science, 53, 1860-1869.

Gauch, H.G. and Zobel, R.W. (1996) AMMI analysis of yield trials. In: "Genotype-by-Environment Interaction". MS Kang, HG Gauch (Ed.), pp. 85122. (CRC Press Publishing Boca Raton, FL).

Gauch, H. and Zobel, R.W. (1997) Identifying megaenvironments and targeting genotypes. Crop Science, 37, 311-326.

Gauch, H.G., Piepho, H.P. and Annicchiarico, P. (2008) Statistical analysis of yield trials by AMMI and GGE: Further considerations. Crop Science, 48, 866-889.

Jacobsen, S.E. (2003) The worldwide potential for quinoa (Chenopodium quinoa Willd.). Food Reviews International, 19, 167-177.

Koziol, M.J. (1993) Quinoa: A potential new oil crop. In: "New Crops". J Janick, JE Simon (Ed.), pp. 328336. (Wiley Publishing New York).

Langer, I., Frey, K.J. and Bailey, T. (1979) Associations among productivity, production response, and stability indexes in oat varieties. Euphytica, 28, $17-24$.

Lin, C.S. and Binns, M.R. (1988) A superiority measure of cultivar performance for cultivar $\times$ location data. Canadian Journal of Plant Science, 68, 193-198.

Lin, C.S., Binns, M.R. and Lefkovitch, L.P. (1986) Stability analysis: Where do we stand? Crop Science, 26, 894-900.

Miranda, G.V., Souza, L.V.D., Guimarães, L.J.M., Namorato, H., Oliveira, L.R. and Soares, M.O.(2009) Multivariate analyses of Genotype×Environment interaction of popcorn. Pesquisa Agropecuária Brasileira, 44, 45-50.

Nassar, R. and Hühn, M. (1987) Studies on estimation of phenotypic stability: Tests of significance for nonparametric measures of phenotypic stability. Biometrics, 43, 45-53.

Osiru, M.O., Olanya, O.M., Adipala, E., Kapinga, R. and Lemaga, B. (2009) Yield stability analysis of Ipomoea batatus L. cultivars in diverse environments. Australian Journal of Crop Science, 3, 213-220.

Pacheco, A., Vargas, M., Alvarado, G., Rodríguez, F., López, M., Crossa, J. and Burgueño, J. (2016) GEA-R (Genotype $\times$ Environment Analysis whit $\mathrm{R}$ for Windows.) Version 4.0, http://hdl.handle. net/11529/10203 International Maize and Wheat Improvement Center.

Perkins, J.M. and Jinks, J.L. (1968) Environmental and genotype-environmental components of variability. Heredity, 23, 339-356.

Prakash, D. and Pal, M. (1998) Chenopodium: Seed protein, fractionation and amino acid composition. International Journal of Food Sciences and Nutrition, 49, 271-275.

Purchase, J.L. (1997) Parametric analysis to describe GenotypexEnvironment interaction and yield stability in winter wheat (Doctoral dissertation, Ph. D. Thesis, Department of Agronomy, Faculty of Agriculture of the University of the Free State, Bloemfontein, South Africa).

Rao, N.K. and Shahid, M. (2012) Quinoa-A promising new crop for the Arabian Peninsula. American Journal of Agricultural and Environmental Sciences, 12, 1350-1355.

Rashidi, M., Farshadfar, E. and Jowkar, M.M. (2013) AMMI analysis of phenotypic stability in chickpea genotypes over stress and non-stress environments. International Journal of Agriculture and Crop Sciences, 5, 253-260.

Repo-Carrasco, R., Espinoza, C. and Jacobsen, S.E. (2003) Nutritional value and use of the Andean crops quinoa (Chenopodium quinoa) and kañiwa (Chenopodium pallidicaule). Food Reviews International, 19, 179-189.

Ruiz, K.B., Biondi, S., Oses, R., Acuña-Rodríguez, I.S., Antognoni, F., Martinez-Mosqueira, E.A., Coulibaly, A., Canahua-Murillo, A., Pinto, M., Zurita-Silva, A. and Bazile, D. (2014) Quinoa biodiversity and sustainability for food security under climate change. A review. Agronomy for Sustainable Development, 34, 349-359.

Ruiz, K.B., Biondi, S., Martínez, E.A., Orsini, F., Antognoni, F. and Jacobsen, S.E. (2016) Quinoa-a model crop for understanding salt-tolerance mechanisms in halophytes. Plant Biosystems-An International Journal Dealing with all Aspects of Plant Biology, 150, 357-371.

Sanchez, H.B., Lemeur, R., Damme, P.V. and Jacobsen, S.E. (2003) Ecophysiological analysis of drought and salinity stress of quinoa (Chenopodium quinoa Willd.). Food Reviews International, 19, 111-119. 
SAS Institute (2003) User manual for SAS for window version 9. Cary, NC: SAS Institute.

Scapim, C.A., Oliveira, V.R., Cruz, C.D., Andrade, C.A.D.B. and Vidigal, M.C.G. (2000) Yield stability in maize (Zea mays L.) and correlations among the parameters of the Eberhart \& Russell, Lin \& Binns and Huehn models. Genetics and Molecular Biology, 23, 387-393.

Shams, A. (2011) Combat degradation in rain fed areas by introducing new drought tolerant crops in Egypt. International Journal of Water Resources and Arid Environments, 1, 318-325.

Spearman, C. (1904) The proof and measurement of association between two things. The American Journal of Psychology, 15, 72-101.

Steel, R.G., Torrie, J.H. and Dickey, D.A. (1980) "Principles and Procedures of Statistics: A Biometrical Approach", (McGraw-Hill publishing: New York).

van Eeuwijk, F.A., Malosetti, M., Yin, X., Struik, P.C. and Stam, P. (2005) Statistical models for genotype by environment data: From conventional ANOVA models to eco-physiological QTL models. Australian Journal of Agricultural Research, 56, 883-894.

Vargas, M., Crossa, J., van Eeuwijk, F.A., Ramírez, M.E. and Sayre, K. (1999) Using partial least squares regression, factorial regression, and AMMI models for interpreting Genotype×Environment interaction. Crop Science, 39, 955-967.

Wricke, G. (1962) On a method for the detection of the ecological spread in field tests. Journal of Plant Breeding, 47, 92.

Yan, W., Hunt, L.A., Sheng, Q. and Szlavnics, Z. (2000) Cultivar evaluation and mega-environment investigation based on the GGE biplot. Crop Science, 40, 597-605.

Yan, W., Kang, M.S., Ma, B., Woods, S. and Cornelius, P.L. (2007) GGE biplot vs. AMMI analysis of genotype-by-environment data. Crop Science, 47, 643-653.

Yang, R.C., Crossa, J., Cornelius, P.L. and Burgueño, J. (2009) Biplot analysis of Genotype $\times$ Environment interaction: Proceed with caution. Crop Science, 49, 1564-1576.

Zobel, R.W., Wright, M.J. and Gauch, H.G. (1988) Statistical analysis of a yield trial. Agronomy Journal, 80, 388-393.

Zurita-Silva, A., Fuentes, F., Zamora, P., Jacobsen, S.E. and Schwember, A.R. (2014) Breeding quinoa (Chenopodium quinoa Willd.): Potential and perspectives. Molecular Breeding, 34, 13-30.

(Received 12 / 2 /2018; accepted 28 / 3 /2018) 


\section{محدات الثبات وتحليل التأثير الرئيسي المضيف والتفاعل المضاعف في الكينوا}

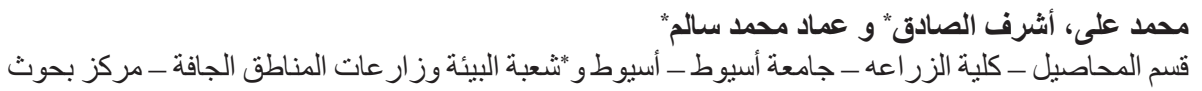

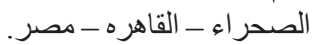

لفحص التركيب الور اثي الثابت يلزم تقدير التفاعل بين التركيب الور اثتي والبيئة في التجارب متعددة البيئات.

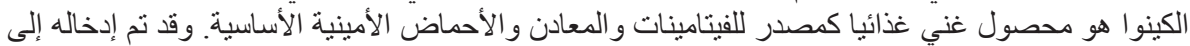

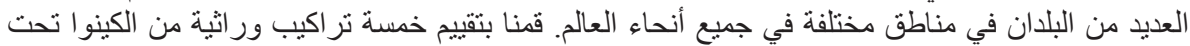

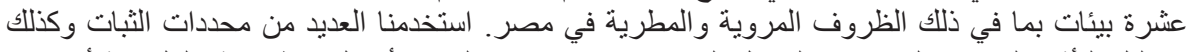

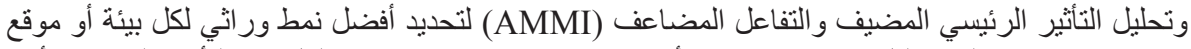

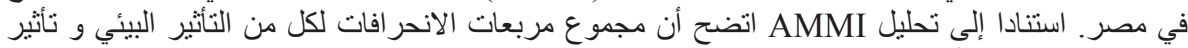

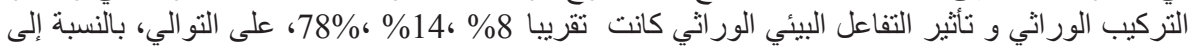

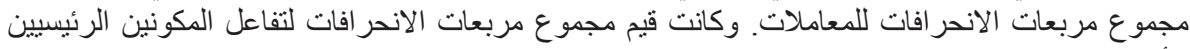

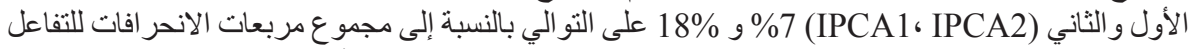

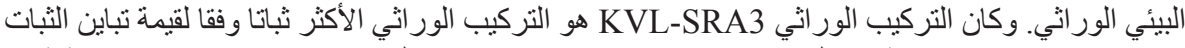

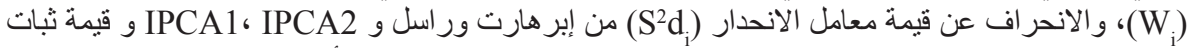
(AMMI (ASV

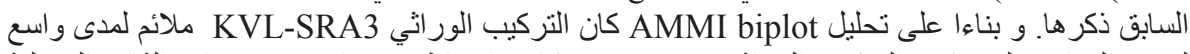

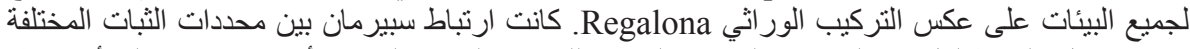

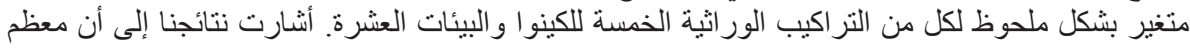

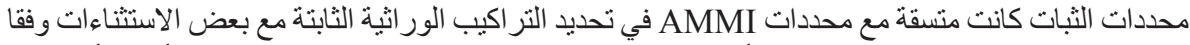

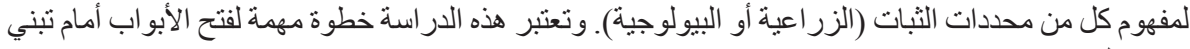
محصول غذائي غير عادي في مصر. 